\title{
Genetic diversity of elephant grass (Cenchrus purpureus [Schumach.] Morrone) for energetic production based on quantitative and multi-category traits
}

María L.F. Oliveira ${ }^{1}$, Rogério F. Daher ${ }^{1}$, Bruna R.S. Menezes ${ }^{2 *}$, Marcelo Vivas ${ }^{1}$,

Avelino dos S. Rocha ${ }^{1}$, Niraldo J. Ponciano ${ }^{1}$, Antônio T. Amaral Junior ${ }^{1}$, Maria do S.B. Araujo ${ }^{1}$, Telma N.S. Pereira ${ }^{1}$, Verônica B. Silva ${ }^{1}$

\section{ABSTRACT}

Elephant grass (Cenchrus purpureus (Schumach.) Morrone) has been used as an alternative source of energy. It is widely cultivated in Brazil, however it needs genotypes adapted to different ecosystems of the country. The knowledge of genetic diversity allows the identification of genotypes that can be used in breeding programs. Thus, this study aimed to evaluate the diversity among 85 genotypes of elephant grass by Tocher's clustering method and by the unweighted pair group method with arithmetic averages (UPGMA), using quantitative and multi-category traits in $2 \mathrm{yr}$ of evaluations. The experiment was implemented in the State Center for Research on Bioenergy and Waste Use at Pesagro-Rio, located in Campos dos Goytacazes, Río de Janeiro, Brazil. Eighty-five elephant grass genotypes donated by the Active Elephant Grass Germplasm Bank of Embrapa Dairy Cattle, in Coronel Pacheco, Minas Gerais, Brazil, were included in the experiment. The experimental design was arranged as randomized blocks, with two replicates. Based on the quantitative traits, the 85 genotypes analyzed belonged to 17 groups according to Tocher's optimization method and to 13 groups when analyzed by UPGMA. For the qualitative traits, however, the genotypes formed 10 groups for both methods. Therefore, the multivariate technique indicated genetic divergences among the genotypes and allowed the formation of similarity groups by Tocher's optimization and UPGMA methods for both the quantitative and qualitative traits.

Key words: Bioenergy, characterization, germplasm, Cenchrus purpureus.

${ }^{1}$ Universidade Estadual do Norte Fluminense Darcy Ribeiro, Campos dos Goytacazes, 28035-200 Rio de Janeiro, Brasil.

${ }^{2}$ Universidade Federal Rural do Rio de Janeiro, 23890-000 Seropédica, Rio de Janeiro, Brasil.

"Corresponding author (brunarafamenezes@hotmail.com).

Received: 19 July 2016.

Accepted: 8 February 2017.

doi:10.4067/S0718-58392017000100006.

\section{INTRODUCTION}

Elephant grass (Cenchrus purpureus Schum.) originated in the subtropical Africa and arrived in Brazil in 1920. It is currently cultivated in the five geographical regions of the country (Quéno et al., 2011). This species has aroused the interest of many researchers for serving as a feedstuff for animals (Valle et al., 2009; Lima et al., 2010), in addition to being a species with high plant biomass production, rapid growth, low cost, and high productivity. For these reasons, it is also being exploited for renewable energy production (Morais et al., 2009).

There is a need for producing genetically improved cultivars of elephant grass adapted to different ecosystems with a faster growth speed and lower seasonality of biomass production over the year (Oliveira et al., 2012). Thus, more in-depth studies on the identification and evaluation in germplasm banks are necessary to reveal genotypes with the best traits of interest for genetic breeding programs (Cavalcante and Lira, 2010).

Easily detectable quantitative and qualitative traits are used to estimate the genetic diversity and to differentiate genotypes (Paiva et al., 2014). The knowledge of the degree of genetic diversity among genotypes in the germplasm bank is important, because such data can provide parameters for identification of the parents, which, when crossed, generate a greater heterotic effect on the progeny and a higher probability of recovering superior genotypes in segregating generations (Cruz et al., 2012).

The Unweighted Pair-Group Method using Arithmetic Averages (UPGMA) provides consistent information that can be used in studies of genetic diversity among elephant grass accessions (Lima et al., 2011). Another method used to quantify the genetic diversity among elephant grass genotypes is Tocher's optimization, associated with the Mahalanobis distance (Oliveira et al., 2014).

Given these above considerations, this study aimed to evaluate the diversity among 85 accessions of elephant grass by Tocher's clustering method and by UPGMA, using 10 quantitative agronomic traits of continuous variation, and 14 qualitative traits of discrete variation, for $2 \mathrm{yr}$.

\section{MATERIALS AND METHODS}

\section{Location and climatic characteristics of the region}

The experiment was carried out at the State Center for Research on Agroenergy and Waste Use at Pesagro-Rio, located in Campos dos 
Goytacazes (2119'23" S, 41¹9'40” W; 20-30 m a.s.1.), Rio de Janeiro, Brazil. According to the Köppen classification system, the climate in the region is an Aw, hot humid tropical type, with dry winters and rainy summers and an annual precipitation around $1152 \mathrm{~mm}$ (Table 1).

The soil is classified as a Yellow Latosol (Embrapa, 2006), with the following properties: $\mathrm{pH}, 5.5 ; 18, \mathrm{mg} \mathrm{P} \mathrm{dm}^{-}$ ${ }^{3} ; 83 \mathrm{mg} \mathrm{K} \mathrm{dm}^{-3} ; 4.6 \mathrm{cmol}_{\mathrm{c}} \mathrm{Ca} \mathrm{dm}^{-3} ; 3.0 \mathrm{cmol}_{\mathrm{c}} \mathrm{Mg} \mathrm{dm}^{-3} ; 0.1$ $\mathrm{cmol}_{\mathrm{c}} \mathrm{Al} \mathrm{dm}{ }^{-3} ; \mathrm{H}+\mathrm{Al}, 4.5 \mathrm{cmol}_{\mathrm{c}} \mathrm{dm}^{-3}$; and $1.6 \% \mathrm{C}$.

\section{Experimental conditions and morpho- agronomic traits}

The experiment comprised 85 genotypes of elephant grass, donated by the Active Elephant Grass Germplasm Bank (Banco Ativo de Germoplasma de Capim-Elefante, BAGCE) of Embrapa Dairy Cattle, located in Coronel Pacheco, Minas Gerais, Brazil (Table 2). The genotypes were planted on 23 and 24 February 2011, using whole stems, distributed into $10 \mathrm{~cm}$-deep furrows. In the planting, $60 \mathrm{~g}$ of single superphosphate were applied, and $50 \mathrm{~d}$ after planting the cover fertilization was performed using $70 \mathrm{~g}$ urea and $40 \mathrm{~g} \mathrm{KCl}$ (potassium chloride) per row, corresponding to $28.6 \mathrm{~kg} \mathrm{~N}$ and $24 \mathrm{~kg} \mathrm{~K} \mathrm{~K}_{2} \mathrm{O}$ (potassium oxide) per hectare.

The experimental design was arranged as randomized blocks with two replicates. The experimental plot consisted of a $5.5 \mathrm{~m}$ row with $2 \mathrm{~m}$ spacing, totaling $11 \mathrm{~m}^{2}$. The plot used measured $1 \mathrm{~m}$.

After the establishment phase, on 15 December 2011, all genotypes were cut near the soil level (plot-leveling cut). The fist harvest for analysis occurred in November 2011, and the second in November 2012, i.e. one harvest per year for a period of $2 \mathrm{yr}$.

Morpho-agronomic traits were evaluated throughout the experiment after each year of continuous growth, analyzing whole-plant samples in all accessions: a) number of tillers per linear meter (NT) was counted in one linear meter per plot; b) plant height $(\mathrm{PH}, \mathrm{m})$ measured with a graduated

Table 1. Precipitation data organized into months, collected near the experimental area during the experiment.

\begin{tabular}{ccccc}
\hline & & & \multicolumn{2}{c}{2013} \\
\cline { 1 - 2 } \cline { 5 - 5 } Month & Precipitation & & Month & Precipitation \\
\hline January & mm & & & mm \\
February & 216.5 & & January & 125.7 \\
March & 11.7 & & February & 44.3 \\
April & 73.6 & & March & 230.2 \\
May & 14.2 & & April & 103.2 \\
June & 147.2 & & May & 41.6 \\
July & 74.0 & & June & 8.7 \\
August & 5.9 & & July & 67.1 \\
September & 59.8 & & August & 57.0 \\
October & 21.6 & & September & 45.2 \\
November & 12.5 & & October & 26.4 \\
December & 133.7 & & November & 158.4 \\
\hline Total & 10.4 & & December & - \\
\hline
\end{tabular}

Source: Evapotranspiration Station of State Center for Research on Bioenergy and Waste Use at Pesagro, Rio, Campos dos Goytacazes, Brazil. ruler, taking one measurement per plot; c) stem diameter $(\mathrm{SD}, \mathrm{cm})$ measured approximately $10 \mathrm{~cm}$ above the soil, taking the average of three measurements, using a digital caliper; d) leaf width and length (LW and LL, respectively, $\mathrm{cm}$ ) measured using a graduated ruler in three samples of each genotype on the $3^{\text {rd }}$ full leaf from the stem apical meristem to the root basal meristem; LW was measured considering the widest part of the leaf. Subsequently, the average of each parameter was calculated separately.

\section{Discrete qualitative (multi-category) traits}

Of the multi-category traits, only the tussock form (TF) was measured in the plots at 12-mo growth; all the others were taken in plots at 6-mo growth so that the advanced growth age of the plants would not interfere in the results. The following discrete qualitative traits were evaluated as described by Daher et al. (1997): a) the tussock form (TF) can assume the following values: 1 open, 2 semiopen, 3 erect; b) overall color of plants in the plot (PC): 1 light green, 2 dark green, 3 purple; c) density of trichomes (hair) on the leaf sheath (TLS): 1 glabrous, 2 lightly pilose, 3 highly pilose; e) leaf angle (LA) in relation to the stem: 1 erect leaves $\left(0\right.$ to $\left.30^{\circ}\right), 2$ semi-erect leaves $\left(30\right.$ to $\left.60^{\circ}\right), 3$ prostrate leaves $\left(60\right.$ to $\left.90^{\circ}\right)$.

\section{Phenological traits}

The phenological traits evaluated were number of days for the appearance of $10 \%$ flag leaf and percentage of flowering at the end of the reproductive period. It was necessary to quantify once weekly the percentage of flowering and the percentage of flag leaves in each accession. Subsequently, it was determined how many days each accession took to emit $10 \%$ flag leaf and, at the end of the flowering days, the total florescence of each genotype. From these data, an analysis of variance (ANOVA) was conducted and the Scott-Knott's clustering was performed at $5 \%$, and then all accessions were classified as follows: a. 1) number of days for the appearance of $10 \%$ flag leaf (Harvest 1: 2012): 1 super early (104 to $124 \mathrm{~d}$ ), 2 early (131 to $145 \mathrm{~d}$ ), 3 regular (147.5 to 173.5 d), 4 late (178 to 209 d); a. 2) number of days for the appearance of $10 \%$ flag leaf (Harvest 2: 2013): 1 super early (122 to $134 \mathrm{~d}$ ), 2 early (138 to $152.5 \mathrm{~d}$ ), 3 regular (156 to $166 \mathrm{~d}), 4$ late (168.5 to $183 \mathrm{~d}$ ); b. 1) percentage of flowering at the end of the reproductive period (Harvest 1: 2012): 1 fully flowering (100\%), 2 partial flowering (60\% to $45 \%), 3$ little flowering (9.5\% to $33 \%)$; b. 2) percentage of flowering at the end of the reproductive period (Harvest 2: 2013): 1 fully flowering $(81.5 \%$ to $100 \%), 2$ partial flowering $(75 \%$ to $55 \%), 3$ little flowering $(26 \%)$.

\section{Statistical analysis}

A simple ANOVA was performed for the quantitative traits in each variable and in each evaluation according to the following model: $Y_{i j}=m+G_{i}+B_{j}+e_{i j}$, where $Y_{i j}$ represents the observation of genotype $i$ in block $i$; 
Table 2. Genotypes present in the Active Elephant Grass Germplasm Bank (Banco Ativo de Germoplasma de Capim-Elefante BAGCE), Campos dos Goytacazes, Rio de Janeiro, 2012-2013.

\begin{tabular}{|c|c|c|}
\hline $\mathrm{N}^{\mathrm{o}}$ & Genotype & Origin \\
\hline 1 & Elefante da Colômbia & Colombia \\
\hline 2 & Mercker & Brazil \\
\hline 3 & Três Rios & Brazil \\
\hline 4 & Napier Volta Grande & Brazil \\
\hline 5 & Mercker Santa Rita & Brazil \\
\hline 6 & Pusa Napier N 2 & India \\
\hline 7 & Gigante de Pinda & Brazil \\
\hline 8 & Napier N 2 & Brazil \\
\hline 9 & Mercker S. E. A & Brazil \\
\hline 10 & Taiwan A-148 & Brazil \\
\hline 11 & Porto Rico 534-B & Brazil \\
\hline 12 & Taiwan A-25 & Brazil \\
\hline 13 & Albano & Colombia \\
\hline 14 & Hib. Gigante Colômbia & Colombia \\
\hline 15 & Pusa Gigante Napier & India \\
\hline 16 & Elefante Híbrido 534-A & Brazil \\
\hline 17 & Costa Rica & Costa Rica \\
\hline 18 & Cubano Pinda & Brazil \\
\hline 19 & Mercker Pinda & Brazil \\
\hline 20 & Mercker Pinda México & Brazil \\
\hline 21 & Mercker 86 México & Colombia \\
\hline 22 & Taiwan A-144 & Brazil \\
\hline 23 & Napier S.E.A. & Brazil \\
\hline 24 & Taiwan A-143 & Brazil \\
\hline 25 & Pusa Napier N 1 & India \\
\hline 26 & Elefante de Pinda & Colombia \\
\hline 27 & Mineiro & Brazil \\
\hline 28 & Mole de Volta Grande & Brazil \\
\hline 29 & Porto Rico & Brazil \\
\hline 30 & Napier & Brazil \\
\hline 31 & Mercker Comum & Brazil \\
\hline 32 & Teresopólis & Brazil \\
\hline 33 & Taiwan A-46 & Brazil \\
\hline 34 & Duro de Volta Grande & Brazil \\
\hline 35 & Mercker Comum Pinda & Brazil \\
\hline 36 & Turrialba & Brazil \\
\hline 37 & Taiwan A-146 & Brazil \\
\hline 38 & Cameroon - Piracicaba & Brazil \\
\hline 39 & Taiwan A-121 & Brazil \\
\hline 40 & Vrukwona & Brazil \\
\hline 41 & P241 Piracicaba & Brazil \\
\hline 42 & IAC-Campinas & Brazil \\
\hline 43 & Elefante Cachoeira Itapemirim & Brazil \\
\hline
\end{tabular}

\begin{tabular}{|c|c|c|}
\hline $\mathrm{N}^{\mathrm{o}}$ & Genotype & Origin \\
\hline 44 & Capim Cana D’África & Brazil \\
\hline 45 & Gramafante & Brazil \\
\hline 46 & Roxo & Brazil \\
\hline 47 & Guaco/I.Z.2 & Brazil \\
\hline 48 & Cuba-115 & Cuba \\
\hline 49 & Cuba-116 & Cuba \\
\hline 50 & Cuba-169 & Cuba \\
\hline 51 & King Grass & Cuba \\
\hline 52 & Roxo Botucatu & Brazil \\
\hline 53 & Mineirão IPEACO & Brazil \\
\hline 54 & Vruckwona Africano & Brazil \\
\hline 55 & Cameroon & Brazil \\
\hline 56 & CPAC & Brazil \\
\hline 57 & Guacu & Brazil \\
\hline 58 & Napierzinho & Brazil \\
\hline 59 & IJ 7125 cv. EMPASC 308 & Brazil \\
\hline 60 & IJ 7126 cv. EMPASC 310 & Brazil \\
\hline 61 & IJ 7127 cv. EMPASC 309 & Brazil \\
\hline 62 & IJ 7136 cv. EMPASC 307 & Brazil \\
\hline 63 & IJ 7139 & Brazil \\
\hline 64 & IJ 7141 cv. EMPASC 306 & Brazil \\
\hline 65 & Goiano & Brazil \\
\hline 66 & CAC-262 & Brazil \\
\hline 67 & Ibitinema & Brazil \\
\hline 68 & 903-77 ou Australiano & Brazil \\
\hline 69 & $13 \mathrm{AD}$ & Brazil \\
\hline 70 & 10 AD IRI & Brazil \\
\hline 71 & 07 AD IRI & Brazil \\
\hline 72 & Pasto Panamá & Panamá \\
\hline 73 & BAG - 92 & Brazil \\
\hline 74 & 09 AD IRI & Brazil \\
\hline 75 & 11 AD IRI & Brazil \\
\hline 76 & 05 AD IRI & Brazil \\
\hline 77 & 06 AD IRI & Brazil \\
\hline 78 & 01 AD IRI & Brazil \\
\hline 79 & 04 AD IRI & Brazil \\
\hline 80 & 13 AD IRI & Brazil \\
\hline 81 & 03 AD IRI & Brazil \\
\hline 82 & 02 AD IRI & Brazil \\
\hline 83 & 08 AD IRI & Brazil \\
\hline 84 & União & Brazil \\
\hline 85 & Pesagro Bord & Brazil \\
\hline
\end{tabular}

represents an overall constant associated with this random variable; $G_{i}$ represents the effect of genotype $i ; B_{j}$ represents the effect of block $j$; and $e_{i j}$ represents the experimental error associated with observation $Y$. Subsequently, the mean Euclidean distance, Tocher's method, UPGMA, and the correlation of quantitative and qualitative matrices by the Mantel test were used for both quantitative and discrete qualitative (multi-category) traits. All of these analyses were performed on GENES software (Cruz, 2013). To quantify the genetic divergence among individuals, the clustering technique based on the mean Euclidean distance, the clustering by Tocher's optimization method (Cruz et al., 2012), and UPGMA were carried out to generate the dendrograms.

\section{RESULTS AND DISCUSSION}

\section{Cluster analyses based on quantitative morpho-agronomic traits}

Using the continuous variables in Tocher's optimization, 16 groups were formed for the 85 elephant grass genotypes (Table 3). Group 1 had the largest number of accessions in its composition: 29 ; i.e. $34.12 \%$ of the accessions. Group 2 was represented by 16 genotypes (18.82\%), and was ranked as the second largest. Another five groups were formed $(13,14,15,16$, and 17), containing only one genotype, as follows: Cubano Pinda (18), Teresópolis (32), CPAC (56), Napierzinho (58), and IJ $7136 \mathrm{cv}$. EMPASC 307 (62). The most genetically similar accessions $(0.2521)$ were Taiwan A-144 (accession 22) and Napier S.E.A (accession 23), and the most distant (2.8425) accessions were 18 (Cubano Pinda) and 69 (13 AD). 
Table 3. Cluster analysis by Tocher's optimization method obtained based on the mean Euclidian distance for 85 genotypes of elephant grass, in Campos dos Goytacazes, Rio de Janeiro, Brazil, 2012-2013.

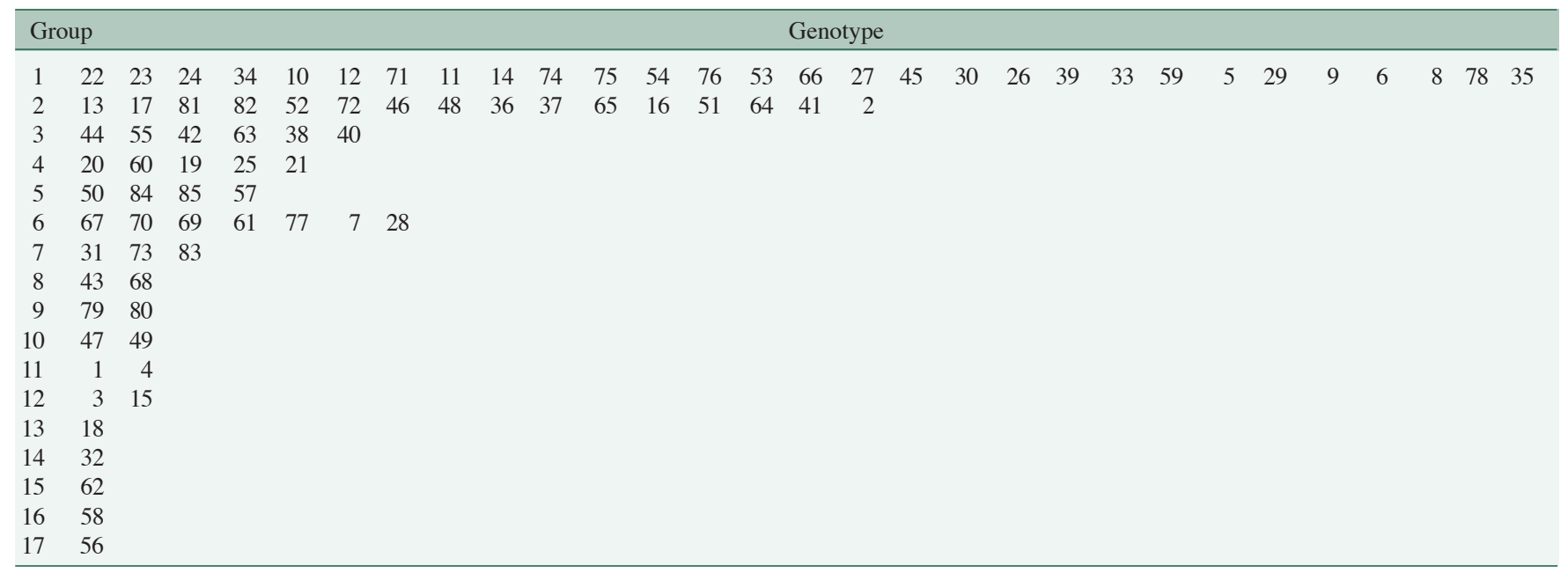

It can be stated that there is a wide genetic diversity among the accessions of this collection, which was revealed by the large number of groups formed and by the satisfactory distribution of accessions among groups. Similar results were found by Leão et al. (2011), who evaluated the genetic diversity of 136 accessions of grape by quantitative morpho-agronomic traits and obtained 30 groups, with the largest concentrating only $30.14 \%$ of the accessions, indicating genetic variability and good division of the accessions among groups. Other studies have demonstrated that the number of groups formed is not always a synonym of high variability, because there may be a great accumulation of genotypes in a single group (Campos et al., 2010; Silva et al., 2013). In interbreeding (crossing), one expects to obtain maximal heterotic effect on the segregating generations, so it should be performed with parents belonging to different dissimilarity groups (Leão et al., 2011).

The UPGMA method, based on the dissimilarity matrix generated by the mean Euclidean distance among the accessions, was used as a criterion for formation of groups in the dendrogram (Figure 1), which shows that there is genetic diversity among the 85 accessions studied due to the formation of 13 distinct groups, considering the harvest on axis y at $58 \%$ relative distance among the accessions. Cruz et al. (2012) argued that the cutoff point that delimits the number of genotypes for each group in the dendrogram should occur at a point of sudden change of level; the cutoff point is thus subjective, and each analysis can indicate a different cutoff point (Rocha et al., 2009; Campos et al., 2010; Monteiro et al., 2010).

From left to right in the dendrogram, group 6 contained the largest number of accessions 28, representing 32.95\% of the total, followed by group 2, with 17 genotypes (20\%). The groups that gathered pairs with shorter distances are usually composed of a large number of accessions (Gomes Filho et al., 2010). The dendrogram also showed two groups (9 and 10) comprising only one accession: IJ $7136 \mathrm{cv}$. EMPASC 307 (62) and Teresópolis (32), respectively.

The UPGMA analysis based on continuous variables has already been applied in several crops, such as cassava. A study evaluating 53 accessions of this plant showed the

Figure 1. Dissimilarity dendrogram based on the quantitative traits dissimilarity matrix obtained by the UPGMA method for 85 genotypes of elephant grass, in Campos dos Goytacazes, Rio de Janeiro, Brazil, 2012-2013.

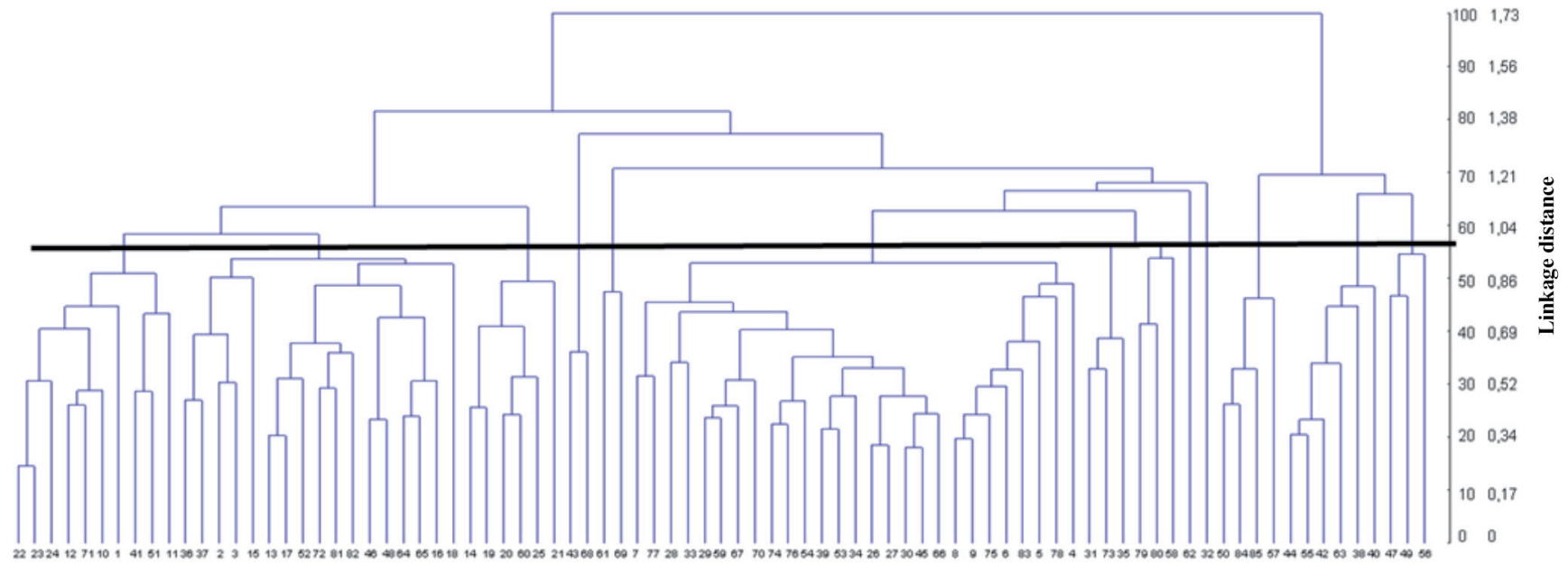


formation of eight dissimilar groups (Campos et al., 2010), and in another study with 46 accessions of papaya, seven groups were formed (Quintal et al., 2012). These results are proportionally similar to the current study regarding the number of groups formed; however, it differs as by the distribution of the genotypes into the groups, given that in the two above-mentioned studies more than $50 \%$ of the accessions were concentrated in only one group (Campos et al., 2010; Quintal et al., 2012), demonstrating that genetic diversity is not well distributed.

However, in other studies, the low diversity was demonstrated by the low number of dissimilarity groups formed in Capsicum ssp. and tomato, in which the evaluations with more than 15 accessions showed the formation of less than five groups (Bento et al., 2007; Gonçalves et al., 2008; Neitzke et al., 2010).

Of the 13 groups formed in the dendrogram (Figure 1), group 1 comprised the genotypes that displayed the greatest plant heights in harvest 2, lowest leaf widths in harvests 1 and 2, lowest leaf lengths in harvest 2, and lowest numbers of tillers per linear meter in harvests 1 and 2 . The genotypes in group 2, however, had the greatest plant heights in harvests 1 and 2, lowest numbers of tillers per linear meter in harvests 1 and 2, and lowest leaf widths and lengths, both in harvest 2 .

Group 3 was formed by the genotypes of greatest plant height and stem diameter in harvest 2 and lowest number of tillers per linear meter, leaf width (both in harvests 1 and 2), and leaf blade in harvest 1 . Group 4 comprised genotypes with the highest numbers of tillers in harvest 1 , highest plant heights in harvest 2, lowest plant heights and leaf lengths in harvest 1 , lowest stem diameter in both harvests, and lower leaf widths in harvest 2.

Group 5 was represented by genotypes with the highest numbers of tillers per linear meter in harvests 1 and 2, lowest plant heights and stem diameters in harvest 1 , and lowest leaf widths and lengths in both harvests. The genotypes from group 6 had the lowest values for plant height and stem diameter in harvest 1 and leaf length in harvests 1 and 2 .

The accessions from group 7 contained the highest numbers of tillers in harvest 1 , the lowest numbers of tillers in harvest 2, the greatest plant heights and stem diameters (both in harvest 1), and the lowest leaf widths and lengths, both in the two harvests. Group 8 was composed of accessions with the lowest values for stem diameter in harvest 1 , stem diameter and plant height in harvest 1, number of tillers per linear meter and leaf length in harvest 2, and leaf width in harvests 1 and 2 .

Groups 9 and 10 comprised only one genotype: IJ 7136 cv. EMPASC 307 and Teresópolis, respectively. The first genotype showed a high value only for the variable number of tillers in harvest 2, whereas the second showed an elevated value only for number of tillers per linear meter in both harvests and for plant height in harvest 2 .

The genotypes from group 11 displayed a high value for leaf length in both harvests, medium values for leaf width in harvest 2, and low values for number of tillers in harvests 1 and 2 . Group 11 contained accessions with high values for stem diameter in harvest 1 and leaf width in harvest 2 , and low values for number of tillers in harvest 1 . The last group included accessions with the highest values for leaf length in harvest 2 , medium values for leaf width in harvest 1 , and low values for number of tillers per linear meter in harvest 2.

The stem diameter is directly related to biomass production. The variable plant height, in turn, may be influenced by the climate and management conditions (Oliveira et al., 2013). The stem diameter is also negatively correlated with the ash content; i.e., as the diameter is reduced the percentage or ash increases, which is desirable in elephant grass for energy biomass production (Rossi et al., 2014). In a study conducted by Menezes et al. (2014), who evaluated elephant-grass genotypes, the authors observed that plant height was the variable that most influenced the trait DM yield in one of the harvests for evaluation, followed by stem diameter and number of tillers.

When comparing the groups formed based on UPGMA with those formed by Tocher's optimization method, there was some agreement regarding the number of groups formed and the number of groups with only one accession. Most accessions that were part of the largest group of UPGMA, group 6, belonged to groups 1 and 6 by Tocher's optimization; only five accessions belonged to the other groups. Group 2, in the dendrogram, the second largest group, comprised mainly the accessions belonging to groups 1 and 2 by Tocher's optimization method; however, two accessions belonged to other groups. The genotypes that did not have enough similarity to form groups with other groups, belonging to single groups, were the same by both Tocher's optimization and the dendrogram, except for genotypes 18,58 , and 56, which only appeared isolated in Tocher's optimization method. Overall, this demonstrates a certain agreement in the formation of groups between Tocher's optimization and UPGMA methods.

Many studies also demonstrated similarity in the number of groups formed (Sobral et al., 2012) and in the clustering of accessions between Tocher's optimization and UPGMA (Bento et al., 2007; Campos et al., 2010; Monteiro et al., 2010). Thus, coupled with Tocher's method, UPGMA provides a more efficient support for the divergence, with Tocher's technique discriminating each group and UPGMA discriminating each accession; in other words, UPGMA features a more complex formation, allowing the visualization of more similar accessions within groups (Campos et al., 2010).

In grouping the genotypes by both Tocher's optimization method and the dendrogram, the variables that contributed most in the division of genotypes, by Singh's approach (Singh, 1981), for the formation of groups, were number of tillers per linear meter in 2012 and in 2013, which, together, contributed with over $80 \%$ (33.50\% and $54.55 \%$, respectively) (Table 4). However, variables that contributed with less than $0.70 \%$ showed little contribution in relation to the others, such as plant height in harvests 1 and 2, leaf 
Table 4. Relative contribution of the traits for genetic diversity of 85 accessions of elephant grass, based on Singh (1981), in Campos dos Goytacazes, Rio de Janeiro, Brazil, 2012-2013.

\begin{tabular}{lc}
\hline Variable & Value $(\%)$ \\
\hline NP1 & 33.50 \\
NP2 & 54.55 \\
ALT1 & 0.01 \\
ALT2 & 0.01 \\
DC1 & 0.28 \\
DC2 & 0.38 \\
LL1 & 0.03 \\
LL2 & 0.02 \\
CL1 & 5.35 \\
CL2 & 5.88 \\
\hline
\end{tabular}

NT1, NT2: number of tillers per linear meter in harvests 1 and 2; PH1, PH2: plant height in harvests 1 and 2; SD1, SD2: stem diameter in harvests 1 and 2; LW1, LW: leaf width in harvests 1 and 2; LL1, LL2: leaf length in harvests 1 and 2 .

width in harvests 1 and 2 (which, summed, did not even contribute with $0.1 \%$ ), and stem diameter in both harvests (Sobral et al., 2012). However, even with little contribution from the above-mentioned traits, it cannot be said that they can be discarded, since Bento et al. (2007) discarded one trait with a percent contribution of $0.01 \%$ and noticed that by discarding it they had changed the formation of groups in Tocher's and UPGMA methods.

\section{Cluster analyses based on the discrete qualitative (multi-category) traits}

With the multi-category traits, the 85 genotypes were clustered into 10 distinct groups by Tocher's optimization method (Table 3). The group that showed the largest number of genotypes was group 1, comprising 34 accessions, or $40 \%$ of the total. The second largest group was group 2, containing 21 accessions $(24.71 \%)$. Additionally, three groups were formed $(8,9$, and 10$)$ with only one accession in their composition, genotypes that were not similar enough to be grouped: P241 Piracicaba (41), Mole de Volta Grande (28), and Roxo Botucatu (52), respectively. According to Gonçalves et al. (2014), Tocher's optimization method allocated traditional accessions of common bean, previously defined as more divergent, to distinct groups separately. These results indicate variability in the germplasm bank, since although $40 \%$ of genotypes are gathered in only one group, 10 groups were formed.

Similar results were obtained by Leão et al. (2011), who evaluated 136 accessions of grape by multi-category descriptors and obtained nine groups formed, with good dispersion of the genotypes in each group, given that the group with the most accessions had 35.3\% of the total 136, indicating great variability. Silva et al. (2013), however, obtained 12 groups, evaluating 88 accessions of coffee, but also reported low variability, with $54.5 \%$ of the accessions in only one group. Likewise, Sudré et al. (2006) obtained 94\% of 59 accessions of pepper and bell pepper into one group only. It is notable that in order to obtain good variability, in addition to the number of groups formed, it is important that the accessions be well distributed within each group.
Hybridization is an important strategy for obtaining superior genotypes in elephant grass (Daher et al., 2014). The knowledge of variability and genetic diversity among genotypes within a germplasm bank allows the identification of parents that, when crossed, generate a greater heterotic effect (Cruz et al., 2012). Menezes et al. (2015) crossed genetically divergent elephant grass genotypes and obtained six hybrids with potential for use in elephant grass breeding programs for energy production.

This type of analysis with multi-category variables is widely adopted, because it demonstrates whether there is variability and because it can be used with different species and different numbers of accessions; for instance, in 16 accessions of corn (Coimbra et al., 2010), 14 accessions of melon (Neitzke et al., 2009), six accessions of dwarf coconut (Sobral et al., 2012), and 26 and 17 accessions of pepper (Monteiro et al., 2010; Neitzke et al., 2010). Nevertheless, it should be stressed that this evaluation has not been largely exploited in elephant grass.

The interpretation of the dendrogram is subjective and may end up generating difficulty in decision-making regarding the cutoff point and consequently the number of groups formed, which may generate different clustering patterns. For this reason, it is recommended to establish a visual examination of points at which dramatic changes in levels occur, thereby allowing the visualization of the groups (Arriel et al., 2006; Cruz et al., 2012).

Thus, by the UPGMA method (Figure 2), considering the harvest on axis y at a 70\% relative distance among accessions, it can be inferred that there is genetic divergence among the 85 accessions studied, due to the formation of 10 distinct groups. The largest group formed, from left to right, was group 1, with 33 accessions, accounting for $38.82 \%$ of all accessions, followed by group 4, with 21 accessions $(24.71 \%)$. Two groups with only one accession were formed, containing accessions 61 (IJ $7127 \mathrm{cv}$. EMPASC 309) and 18 (Cubano Pinda).

Group 1 in the dendrogram gathered all plants considered super early and completely flowered at the end of the reproductive cycle in both harvests 1 and 2, except for genotype IJ $7141 \mathrm{cv}$. EMPASC 306 (64), which was considered partially flowered in harvest 1 and late in harvests 1 and 2. As regards the tussock form, group 1 ranged between semi-open and erect, and for the general color of the plants in the plot, this group contained the light green and dark green genotypes; however, the hairiness and angle of the leaves varied largely, featuring all varieties.

Group 2 in the dendrogram included only genotype IJ 7127 cv. EMPASC 309 (61), considered super early, fully flowered at the end of the reproductive period, and with prostrate leaves. Group 3 gathered plants that showed complete flowering at the end of the reproductive period, with leaf angle and tussock form mostly erect.

In the second largest group, 4 in the dendrogram, the accessions were all early and were completely flowered at the end of the reproductive period, displaying an overall plant color in the plot varying from light to dark green, 
Figure 2. Dissimilarity dendrogram based on the multi-category traits dissimilarity matrix obtained by UPGMA method for 85 genotypes of elephant grass, in Campos dos Goytacazes, Rio de Janeiro, Brazil, 2012-2013.

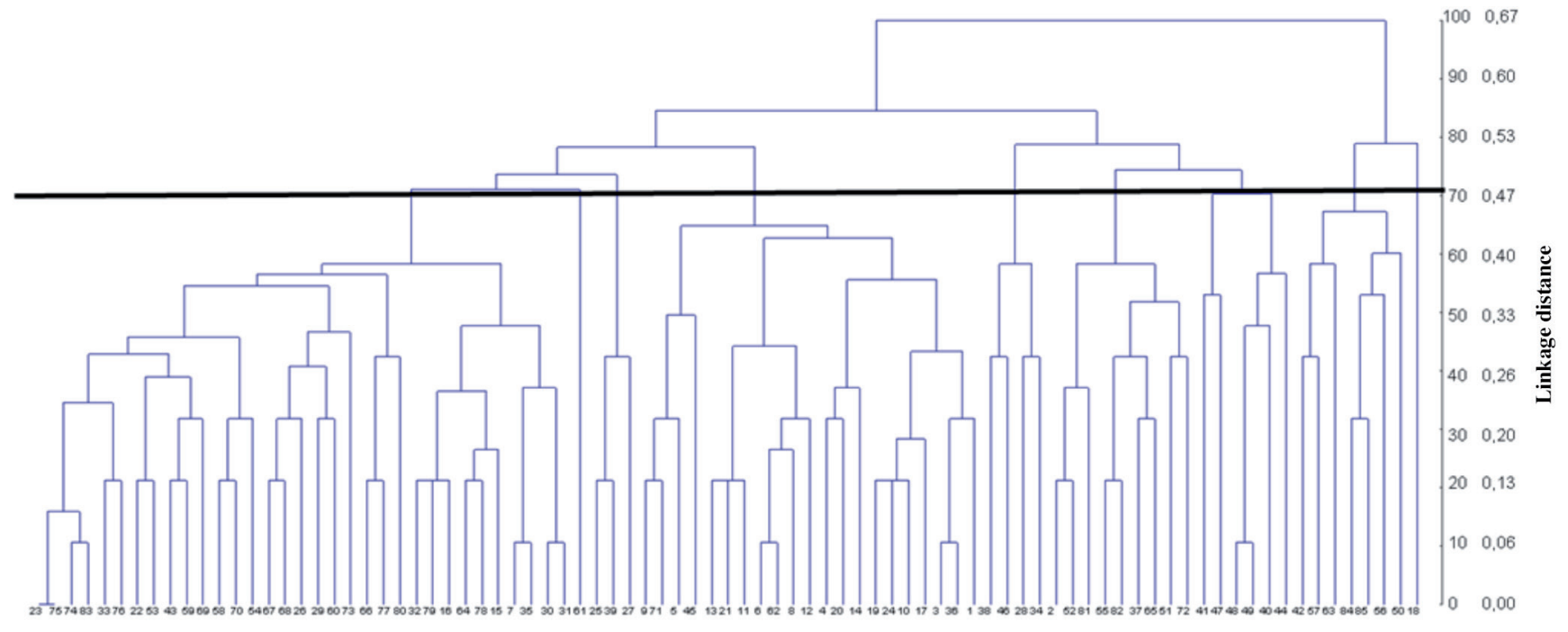

open or semi-open tussock, and erect or semi-erect leaf. All genotypes from group 5 showed erect flowers, and were completely flowered at the end of the reproductive period, with the hairiness varying from glabrous (no hair) in genotypes Mole de Volta Grande (28) and Duro de Volta Grande (34) to lightly pilose in the others.

Group 6 was composed of accessions with a medium number of days for appearance of $10 \%$ flag leaf, completely flowered at the end of the reproductive period. The leaf angle found in this group was erect and semi-erect, and the majority of the leaf sheaths in the group was lightly pilose. Group 7 was characterized by all genotypes being light green, with an erect leaf angle, early, and completely flowered at the end of the reproductive period.

Accessions with erect leaves, open tussock, light green color, lightly pilose, and with a medium number of days for the appearance of $10 \%$ flag leaf were gathered in group 8 . Group 9, in turn, had late accessions with light green color of the plot and tussock varying from open to semi-open. Group 1 was formed by only one accession, Cubano Pinda (18), which showed an erect leaf angle and late appearance of $10 \%$ flag leaf. Late flowering is a desirable feature in elephant grass genotypes intended for energy production. However, Oliveira et al. (2015) observed that this same genotype displayed the highest dry matter yield at higher levels of $\mathrm{N}$ fertilization, which is not desirable.

The UPGMA clustering method is considered the most simple for the construction of phylogenetic trees, frequently used in the study of variability of germplasms of several species (Campos et al., 2010; Scheffer-Basso et al., 2012; Sobral et al., 2012). It is sufficient for both continuous (Coimbra et al., 2010) and multi-category (Bento et al., 2007; Büttow et al., 2010) variables.

The efficiency of use of multi-category variables in the discrimination of genotypes has been demonstrated by some authors; e.g. Sudré et al. (2006), who evaluated genetic diversity among genotypes of Capsicum ssp., and
Campos et al. (2010), who evaluated genetic diversity among accessions of cassava and determined the efficiency of use of multi-category variables in the discrimination of genotypes, demonstrating the great potential of use in characterization and management of germplasm banks.

The use of multi-category variables showed to be efficient in demonstrating the genetic variability, and was also an easy technique due to its easy observation, practicality, and for requiring less labor and less time as compared with quantitative data, which render it ideal for banks and collections when little human and financial resource is available. However, it should be stressed that each method has its unique importance, and it is preferred that a collection be studied in depth so that it can provide greater support to breeding programs (Sudré et al., 2006; Bento et al., 2007; Neitzke et al., 2009). For this reason, when analyzing the diversity by qualitative variables, many studies also analyze them quantitatively (Bento et al., 2007; Neitzke et al., 2009; Campos et al., 2010; Silva et al., 2013), as in this study.

In the comparison between the dendrogram and Tocher's optimization of the multi-category variables, there was a similarity in the number of groups formed; however, by Tocher's method, three groups had one accession in their composition, whereas in the dendrogram, two groups were identified as having one accession. Curiously, of all accessions that were part of group 1 in the dendrogram, only one was not represented in group 1 by Tocher's optimization method: genotype 13 AD IRI (80), which belonged to group 6 by Tocher's method. Of all genotypes in group 4 in the dendrogram, only four accessions did not belong to group 2 in the optimization: 71 (07 AD IRI), 45 (Gramafante), 62 (IJ $7136 \mathrm{cv}$. EMPASC 307), and 36 (Turrialba), demonstrating a certain similarity between the two analyses.

The few disagreements that occurred can be explained by the fact that different methods utilize distinct procedures for the formation of groups; i.e., each method utilizes 
different calculations to determine genetic distance (Neitzke et al., 2009; Büttow et al., 2010). Thus, it is normal that most studies comparing these two methods yield a partially agreeing result (Neitzke et al., 2009; Büttow et al., 2010; Campos et al., 2010). Another fact worth mentioning is that UPGMA provided a more detailed demonstration, allowing the visualization of the distances within a given group, complementing Tocher's method, which already provided the distinct groups (Campos et al., 2010).

\section{Correlation between continuous discrete variables and multi-category variables}

The estimate of the correlation coefficient tested by the Mantel test between the dissimilarity matrices obtained based on the continuous or multi-category variables helps to determine the discordance among the clusters formed for each set of traits, both quantitative or multi-category (Silva et al., 2013). The correlation estimate had a high magnitude (0.41) that was significant at $1 \%$, demonstrating that the diversity from a dataset can be extrapolated into another dataset of a different nature (Silva et al., 2013). This result corroborated Gonçalves et al. (2008), who found a similar magnitude $(0.40)$ in tomato, explaining that the techniques utilized addressed different regions in the genome.

A correlation lower than 0.10 suggests that the genetic diversity obtained based on the quantitative traits does not explain the diversity of the multi-category traits (Silva et al., 2013). This was the case presented by Silva et al. (2013), who reported a nonsignificant correlation of 0.02 in coffee, and by Quintal et al. (2012), who obtained an also nonsignificant magnitude of 0.25 for papaya.

In comparing the quantitative matrices with the multicategory one, in Tocher's optimization for the continuous variables with Tocher's optimization for the multi-category traits, the former demonstrated variability of germplasm bank better, as it formed more groups than the latter, distributing the accessions more according to their genetic diversity.

Tocher's optimization method also did not show a pattern; i.e., the genotypes grouped quantitatively in a same group were dispersed, composing different groups when grouped by multi-category traits, whereas genotypes that were isolated making single groups formed groups of similarity with the other genotypes.

Silva et al. (2013), Neitzke et al. (2010), and Leão et al. (2011) also found a different number of groups and differentiated distribution of the accessions into the groups when comparing the cluster formed by quantitative and multi-category traits with 88 accessions of Coffea ssp., 17 accessions of pepper, and 136 accessions of grape, respectively. For that reason, Coimbra et al. (2010) stated that these pieces of information on similarity should be used together. Corroborating this assertion, Silva et al. (2013) obtained low genetic diversity among accessions when considering quantitative and multicategory traits separately.

Dendrograms of continuous and discrete variables presented similar numbers of groups, meaning that both the quantitative and the multi-category descriptors, in UPGMA, showed the existence of a broad genetic diversity in the germplasm bank. However, genotypes that formed the group in the quantitative analysis were grouped with other genotypes in the quantitative analysis; i.e., genotypes that formed groups in the continuous variables were not the same that formed groups in the discrete variables. This result corroborates the study of Gonçalves et al. (2008), in which the same number of groups was formed but there was a great difference in the distribution of accessions into the groups.

Most studies demonstrate that, by the UPGMA clustering method, qualitative variables have a greater efficiency in the separation of genotypes, indicating a greater participation of qualitative variables in the explanation of the clusters formed. This might have occurred here, though, since the majority of descriptors utilized was quantitative (Monteiro et al., 2010; Moura et al., 2010; Neitzke et al., 2010). Hence, quantitative descriptors must be used in the study of genetic diversity, as they possess great relevance to breeding programs (Moura et al., 2010).

The combined analysis of quantitative and qualitative data can provide better understanding of the genetic diversity of the bank; i.e., a more complete characterization of the genotypes and genetic diversity patterns serves as basis for more efficient breeding research, facilitating the study of diversity (Gonçalves et al., 2008; Campos et al., 2010; Moura et al., 2010). Therefore, the combined analysis of quantitative and multi-category data provides a reliable genetic interpretation and allows for better directions for elephant grass crosses in breeding programs (Neitzke et al., 2010).

\section{CONCLUSION}

There is genetic dissimilarity among studied accessions of Cenchrus purpureus, which was demonstrated in the analysis of quantitative and qualitative traits. This dissimilarity can be exploited for forming crossing blocks in breeding programs aimed at the development of cultivars with the most diversified purposes, as is the case of biomass energy production.

The analysis of quantitative data separated the accessions more, forming a larger number of groups than the qualitative analysis did; however, the qualitative analysis should not be excluded, as it also allowed the clustering of genotypes. Comparing all groups, no clustering pattern could be observed.

The characterization based on quantitative descriptors and characterization based on qualitative descriptors provide data that allow a better interpretation of the genetic dissimilarity and better direction for the elephant grass crosses in breeding programs.

\section{ACKNOWLEDGEMENTS}

To Fundação de Amparo a Pesquisa do Estado do Rio de Janeiro for providing the fellowships and the financial support for this study. 


\section{REFERENCES}

Arriel, N.H.C., Di Mauro, A.O., Di Mauro, S.M.Z., Bakkes, A.O., Unêda-Trevisol, S.H., Costa, M.M., et al. 2006. Técnicas multivariadas na determinação da diversidade genética em gergelim usando marcadores RAPD. Pesquisa Agropecuária Brasileira 41:801-809. doi:10.1590/S0100204X2006000500012.

Bento, C.S., Sudre, C.P., Rodrigues, R., Riva, E.M., e Pereira, M.G. 2007. Descritores qualitativos e multicategóricos na estimativa da variabilidade fenotípica entre acessos de pimentas. Scientia Agricola 8:149-156.

Büttow, M.V., Barbieri, R.L., Neitzke, R.S., Heiden, G., e Carvalho, F.F.I. 2010. Diversidade genética entre acessos de pimentas e pimentões da Embrapa Clima Temperado. Ciência Rural 40:1264-1269. doi:10.1590/S0103-84782010000600004.

Campos, A.L., Zacarias, A.J., Costa, D.L., Neves, L.G., Barelli, M.A.A., Sobrinho, S.P., et al. 2010. Avaliação de acessos de mandioca do banco de germoplasma da UNEMAT Cáceres Mato Grosso . Revista Trópica: Ciências Agrárias e Biológicas 4:44-54

Cavalcante, M., e Lira, M.A. 2010. Variabilidade genética em Pennisetum purpureum Schumacher. Revista Caatinga 23:153-163.

Coimbra, R.R., Miranda, G.V., Cruz, C.D., Melo, A.V., e Eckert, F.R. 2010. Caracterização e divergência genética de populações de milho resgatadas do Sudeste de Minas Gerais. Revista Ciência Agronômica 41:159-166.

Cruz, C.D. 2013. GENES - a software package for analysis in experimental statistics and quantitative genetics. Acta Scientiarum. Agronomy 35:271-276. doi:10.4025/actasciagron. v35i3.21251

Cruz, C.D., Regazzi, A.J., e Carneiro, P.C.S. 2012. Métodos biométricos aplicados ao melhoramento genético. UFV Imprensa Universitária, Viçosa, Minas Gerais, Brasil.

Daher, R.F., Moraes, C.F., Cruz, C.D., Pereira, A.V., e Xavier, D.F. 1997. Seleção de caracteres morfológicos discriminantes em capim elefante (Pennisetum purpureum Schum.) Revista Brasileira de Zootecnia 26:247-254.

Daher, R.F., Souza, L.B., Gravina, G.A., Machado, J.C., Ramos, H.C.C., Silva, V.Q.R., et al. 2014. Use of elephant grass for energy production in Campos dos Goytacazes-RJ, Brazil. Genetics and Molecular Research 13:10898-10908. doi:10.4238/2014.December.19.11

Embrapa. 2006. Sistema brasileiro de classificação de solos. Empresa Brasileira de Pesquisa Agropecuária, Embrapa Solos, Rio de Janeiro, Brasil.

Gomes Filho, A., Oliveira, J.G., Viana, A.P., Siqueira, A.P.O., Oliveira, M.G., e Pereira, M.G. 2010. Marcadores moleculares RAPD e descritores morfológicos na avaliação da diversidade genética de goiabeiras (Psidium guajava L.) Acta Scientiarum. Agronomy 32:627-633. doi:10.4025/actasciagron.v32i4.4720.

Gonçalves, D.L., Ambrozio, V.C., Barelli, M.A.A., Neves, L.G., Sobrinho, S.P., Luz, P.B., et al. 2014. Divergência genética de acessos tradicionais de feijoeiros através de características da semente. Bioscience Journal 30:1671-1681.

Gonçalves, L.S.A., Rodrigues, R., Amaral Junior, A.T., Karasawa, M., and Sudre, C.P. 2008. Comparison of multivariate statistical algorithms to cluster tomato heirloom accessions. Genetics and Molecular Research 7:1289-1297.
Leão, F.F., Davide, L.C., Campos, J.M.S., Pereira, A.V., and Bustamante, F.O. 2011. Genomic behavior of hybrid combinations between elephant grass and pearl millet. Pesquisa Agropecuária Brasileira 46:712-719. doi:10.1590/S0100204X2011000700006.

Lima, R.S.N., Daher, R.F., Goncalves, L.S.A., Rossi, D.A., Amaral Junior, A.T., Pereira, M.G., et al. 2011. RAPD and ISSR markers in the evaluation of genetic divergence among accessions of elephant grass. Genetics and Molecular Research 10:1304-1313. doi:10.4238/vol10-3gmr1107.

Lima, E.S., Silva, J.F.C., Vasquez, H.M., Andrade, E.N., Deminicis, B.B., Morais, J.P.G., et al. 2010. Características agronômicas e nutritivas das principais cultivares de capimelefante do Brasil. Veterinária e Zootecnia 17:324-334.

Menezes, B.R.S., Daher, R.F., Gravina, G.A., Amaral Júnior, A.T., Oliveira, A.V., Schneider, L.S.A., et al. 2014. Correlações e análise de trilha em capim-elefante para fins energéticoselefante. Revista Brasileira de Ciências Agrárias 9:465-470. doi:10.5039/agraria.v9i3a3877.

Menezes, B.R.S., Daher, R.F., Gravina, G.A., Pereira, A.V., Sousa, L.B., Rodrigues, E.V., et al. 2015. Estimates of heterosis parameters in elephant grass (Pennisetum purpureum Schumach.) for bioenergy production. Chilean Journal of Agricultural Research 75:395-401. doi:10.4067/S071858392015000500003.

Monteiro, E.R., Bastos, E.M., Lopes, A.C.A., Ferreira, G.R.L., e Rodrigues, N.J.A. 2010. Diversidade genética entre acessos de espécies cultivadas de pimentas. Ciência Rural 40:288-293. doi:10.1590/S0103-84782010005000015.

Morais, R.F., Souza, B.J., Leite, J.M., Soares, L.H.B., Alves, B.J.R., Boddey, R.M., et al. 2009. Elephant grass genotypes for bioenergy production by direct biomass combustion. Pesquisa Agropecuária Brasileira 44:133-140. doi:10.1590/S0100204X2009000200004.

Moura, M.C.C.L., Gonçalves, L.S.A., Sudré, C.P., Rodrigues, R., Amaral Junior, T.A., e Pereira, T.N.S. 2010. Algoritmo de Gower na estimativa da divergência genética em germoplasma de pimenta. Horticultura Brasileira 28:155-161. doi:10.1590/ S0102-05362010000200003.

Neitzke, R.S., Barbieri, R.L., Heiden, G., Büttow, M.V., Oliveira, C.S., Corrêa, L.B., et al. 2009. Caracterização morfológica e dissimilaridade genética entre variedades crioulas de melão. Horticultura Brasileira 27:534-538.

Neitzke, R.S., Barbieri, R.L., Rodrigues, W.F., Corrêa, I.V., e Carvalho, F.I.F. 2010. Dissimilaridade genética entre acessos de pimenta com potencial ornamental. Horticultura Brasileira 28:47-53. doi:10.1590/S0102-05362010000100009.

Oliveira, M.L.F., Daher, R.F., Gravina, G.A., Silva, V.B., Viana, A.P., Rodrigues, E.V., et al. 2014. Pre-breeding of elephant grass for energy purposes and biomass analysis in Campos dos Goytacazes-RJ, Brazil. African Journal of Agricultural Research 9:2743-2758. doi:10.5897/ajar2014.8900.

Oliveira, A.V., Daher, R.F., Menezes, B.R.S., Gravina, G.A., Sousa, L.B., Gonçalves, A.C.S., et al. 2013. Avaliação do desenvolvimento de 73 genótipos de capim-elefante em Campos dos Goytacazes - RJ. Boletim de Indústria Animal 70:119-131.

Oliveira, E.S., Daher, R.F., Ponciano, N.J., Gravina, G.A., Sant'ana, J.A.A., Gottardo, R.D., et al. 2015. Variation of morpho-agronomic and biomass quality traits in elephant grass for energy purposes according to nitrogen levels. American Journal of Plant Sciences 6:1685-1696. doi:10.4236/ ajps.2015.611168. 
Oliveira, E.S., Daher, R.F., Tunes, E.N., Soares, R.T.R.N., Gonçalves, A.C.S., e Gravina, G.A. 2012. Potencial de germinação de estacas e avaliação de características morfoagronômicas em seis cultivares de capim-elefante (Pennisetum purpureum Schum.) para fins energéticos em Campos dos Goytacazes, RJ. Natureza (Online) 10:39-45.

Paiva, C.L., Viana, A.P., Santos, E.A., Silva, R.N.O., e Oliveira, E.J. 2014. Diversidade genética de espécies do gênero Passiflora com o uso da estratégia Ward-MLM. Revista Brasileira de Fruticultura 36:381-390. doi:10.1590/0100-2945-156/13.

Quéno, L.M.R., Souza, Á.N., Ângelo, H., Vale, A.T., e Martins, I.S. 2011. Custo de produção das biomassas de eucalipto e capimelefante para energia. CERNE 17:417-426.

Quintal, S.S.R., Viana, A.P., Azeredo, G.L.S., Pereira, M.G., e Amaral Junior, A.T. 2012. Divergência genética entre acessos de mamoeiro por meio de variáveis morfoagronômicas. Semina Ciências Agrárias 33:131-142. doi:10.5433/16790359.2012v33n1p131.

Rocha, M.C., Azeredo, G.L.S., Correa, F.M., Rodrigues, R., Silva, S.L., Souza, A.C.A., et al. 2009. Descritores quantitativos na determinação da divergência genética entre acessos de tomateiro do grupo cereja. Ciência Rural 39:664-670. doi:10.1590/S010384782008005000092.

Rossi, D.A., Menezes, B.R.S., Daher, R.F., Gravina, G.A., Lima, R.S.N., Lédo, F.J.S., et al. 2014. Canonical correlations in elephant grass for energy purposes. African Journal of Biotechnology 13:3666-3671. doi:10.5897/AJB2014.13915.
Scheffer-Basso, S.M., Orsato, J., Moro, G.V., e Albuquerque, A.C.S. 2012. Divergência genética em germoplasma de aveias silvestres com base em caracteres multicategóricos e quantitativos. Ceres 59:654-667. doi:10.1590/S0034737X2012000500011.

Singh, D. 1981. The relative importance of characters affecting genetic divergence. Indian Journal of Genetics and Plant Breeding 41:237-245.

Silva, F.L., Baffa, D.C.F., Oliveira, A.C.B., Pereira, A.A., e Bonomo, V.S. 2013. Integração de dados quantitativos e multicategóricos na determinação da divergência genética entre acessos de cafeeiro. Bragantia 72:224-229. doi:10.1590/ brag.2013.039.

Sobral, K.M.B., Ramos, S.R.R., Gonçalves, L.S.A., Amaral Junior, A.T., e Aragão, W.M. 2012. Variabilidade genética entre acessos de coqueiro-anão utilizando técnicas de análise multivariada. Magistra 24:348-459.

Sudré, C.P., Cruz, C.D., Rodrigues, R., Riva, E.M., Amaral Junior, A.T., Silva, D.J.H., et al. 2006. Variáveis multicategóricas na determinação da divergência genética entre acessos de pimenta e pimentão. Horticultura Brasileira 24:88-93.

Valle, C.B., Jank, L., and Resende, R.M.S. 2009. Tropical forage breeding in Brazil. Ceres 56:460-472. 